\title{
Ebola is now "preventable and treatable," says WHO after approving vaccine in record time
}

\author{
Elisabeth Mahase
}

The BMJ

The World Health Organization has prequalified the injectable Ebola vaccine Ervebo in a move that will speed up its licensing, access, and roll-out in countries most at risk of Ebola virus outbreaks.

This is the fastest vaccine prequalification process ever conducted by WHO and means that the vaccine has met WHO standards for quality, safety, and efficacy. Ervebo can now be procured by United Nations agencies and Gavi, the vaccine alliance, for countries at risk.

WHO's approval on 12 November came just a day after the European Commission granted a conditional marketing authorisation for the vaccine, after its own fast tracked review. The commission's legal approval came after the European Medicines Agency had assessed the benefits and risks of the vaccine.

WHO and the European Medicines Agency are also working with many African regulators, which have indicated that they will quickly license the vaccine after WHO's recommendation.

\section{Greater availability}

Ervebo, which is manufactured by Merck Sharp \& Dohme (MSD), has been in development since the 2014 Ebola outbreak in west Africa and is already used to protect people at risk of infection, such as healthcare workers or people who have been exposed to infected patients.

In its announcement WHO said that the prequalification was a "step towards greater availability of the vaccine in the future, though licensed doses will only be available mid-2020."

Tedros Adhanom Ghebreyesus, WHO director general, said, "This is a historic step towards ensuring the people who most need it are able to access this lifesaving vaccine. Five years ago, we had no vaccine and no therapeutics for Ebola. With a prequalified vaccine and experimental therapeutics, Ebola is now preventable and treatable.

"The development, study, and rapid prequalification of this vaccine show what the global community can do when we prioritise the health needs of vulnerable people."

The Democratic Republic of the Congo is currently battling the world's second largest Ebola epidemic on record, which began in 2018 and has so far seen 3168 confirmed cases and 2191 deaths as of 6 November 2019.

The latest figures show that transmission is slowing, as the number of health zones reporting active transmission is declining. Of the 29 zones that have reported at least one case since August 2018, only seven confirmed new cases in the 21 days before 6 November.

Christos Stylianides, commissioner for Humanitarian Aid and Crisis Management and European Union Ebola coordinator, said, "The European Union is supporting international efforts to combat Ebola on all fronts, from vaccine development to delivering humanitarian aid on the ground. We will continue assisting the fight to tackle the epidemic for as long as it takes."

1 Public Health England. Health Protection Report-volume 13 issue 40: news (8 November). 8 Nov 2019. https://www.gov.uk/government/publications/health-protection-report-volume13-2019/hpr-volume-13-issue-40-news-8-november\#evd-outbreak-in-eastern-drc-fifteenthupdate.

Published by the BMJ Publishing Group Limited. For permission to use (where not already granted under a licence) please go to http://group.bmj.com/group/rights-licensing/ permissions 